\title{
Accounting Information and Cost of Capital: A Theoretical Approach
}

\author{
Nicholas Apergis $^{1 *}$, George Artikis ${ }^{2}$, Sofia Eleftheriou ${ }^{2}$, John Sorros ${ }^{2}$ \\ ${ }^{1}$ Department of Banking \& Financial Management, University of Piraeus, Piraeus, Greece \\ ${ }^{2}$ Department of Business Administration, University of Piraeus, Piraeus, Greece \\ E-mail: $\left\{{ }^{*}\right.$ napergis, gartik, sofelef, sorros\}@unipi.gr \\ Received April 12, 2011; revised June 5, 2011; accepted June 15, 2011
}

\begin{abstract}
The primary goal of this study is to provide a theoretical model that shows explicit solutions for equilibrium prices and derives the equilibrium required return for the firm's stock price. In other words, this theoretical study provides a direct link between accounting information, related to the firm's reports, and the cost of capital within an equilibrium setting. Accounting information is judged to be of high value because it affects the market's ability to direct firms' capital allocation choices. The findings showed that an increase in expected cash flows, coming from improvements in the quality of accounting information, leads to a reduction in the firm's cost of capital.
\end{abstract}

Keywords: Theoretical Model, Accounting Information, Cost of Capital, Stock Returns

\section{Introduction and Literature}

One of the key decisions a firm has to reach is the fundamental determination of its cost of capital. This has a substantial impact on both the composition of the firm's operations and its profitability, since shocks onto anticipated cash flows are reflected in the firm's cost of capital. Many studies have spent tons of ink coming up with proposals leading to a lower cost of capital. [1] argue that it is the environment of a firm, which is described by many parameters, such as accounting standards, market microstructure and information coming from the firm's reports, that really influences the accounting type of information that determines the firm's cost of capital and, consequently, its stock price.

Accounting information reduces information asymmetries, which lead to adverse selection in transaction activities in the stock market ([2]) as well as to enhanced liquidity, which lowers the discounts at which firms must issue capital ([3]). [4] argue that accounting information tends to compensate shareholders through stock returns by reducing their exposure to investment risks. Research in asset-pricing models has not, so far, modelled explicitly the accounting information environment in determining the firm's required return, though [5] argue that more factors other than market risk could be equally responsible for determining a firm's financial aggregates, such as stock returns. Neglecting such a factor, however, places the concept of market efficiency in serious dispute, a fact that played a prominent role in the recent global financial crisis. According to [6], although theoretical arguments support the view that new accounting information leads to changes not only in firm's stock prices, but also in the traded volume due to the enhanced effect of informed traders, the empirical evidence does not seem supportive to the above argument. [6] finds that excess returns do change upon the arrival of new accounting information, but only if the new information set can impact the trading activity, the firm's ownership characteristics, and the family-firm status.

This study is an extension of two empirical works by $[7,8]$ that investigate empirically the impact of accounting information on the firm's cost of capital and, then, on firm's stock returns. Their result present that certain accounting information variables, directly related to the firm's operation and originated from the firm's financial reports, exert a true impact on the cost of capital and, thus, on firm's stock returns. While the empirical analysis provides some important results in the relevant literature, a theoretical model is needed to support those empirical findings. Thus, the primary goal, and the novelty as well, of this study is to provide a theoretical model that shows explicit solutions for equilibrium prices and also derives the equilibrium required return for the firm's 
stock. In other words, it attempts to investigate the link between accounting information and the firm's cost of capital. To the extent that accounting information affects expected cash flows, it also affects the firm's costs of capital. Therefore, this theoretical study will provide a direct link between accounting information related to the firm's reports and the cost of capital (so as between the cost of capital and firm's stock returns) within an equilibrium setting. Accounting information is judged to be of high value because it affects the market's ability to direct firms' capital allocation choices. Moreover, higher accounting information improves the coordination between firms and investors with respect to capital investment decisions, resulting in an increase in expected cash flows without a commensurate increase in the firm's covariance with the market, which is expected to have a negative effect on the firm's cost of capital.

At this point we will attempt to connect the derived equilibrium stock price to the pieces of accounting information used in the empirical studies by $[7,8]$ and to justify their empirical findings. At this point, we explicitly mention that emphasis is given on the disclosure of public information. [9] investigate the separation between public and private information and their role for the firm's cost of capital. They find that private information increases the risk to uninformed investors of holding the firm's stock, once informed investors are more capable of shifting their portfolio weights to incorporate new information. They also determine how in equilibrium the quantity and quality of information affects asset prices, leading to cross-sectional differences in firm's required returns. In such a framework, an individual firm can influence its cost of capital by choosing features like its accounting treatments and market microstructure. Their explicit suggestion is that more information is better than no information at all.

Overall, a firm's information structure affects its stock return. This dictates that a firm's cost of capital is influenced by information, providing an important linkage between asset pricing and the information structure of corporate securities.

Certain studies have attempted in the past to determine the role of accounting information. Empirical studies in the issue suggest that accounting information is negatively associated with the firm's cost of capital ([10-12]).

One main stream of related literature exemplifies the role of incomplete information. [13] investigates how the uncertainty, surrounding the presence of certain assets, influences capital market equilibrium conditions. Here the term incomplete is defined in a sense that not all potential investors know about every asset. His results display that in equilibrium the value of the firm is always lower under incomplete information conditions, while better information reduces the rate of return demanded by investors by improving risk sharing. The same results are also displayed by [14] through a reduction in estimation risk. However, [15] dispute the mechanism of estimation risk on the grounds that the effect of the investor base is susceptible to arbitrage, while there is much debate about the diversifiability and pricing of such risk, while [11] find a negative impact running from accounting information and the cost of capital. They find, however, that the association turns positive if higher levels of accounting information are caused by higher stock price volatility. [16] explore the relationship between the role of strategic disclosures and the cost of equity capital. Based on theoretical arguments, the association is expected to be negative, though the empirical analysis is mixed. Their empirical findings, however, confirm the above mentioned negative relationship due to the fact that their innovative model considers explicitly the role of timely strategic disclosure drawing on standardised Regulatory News Service (RNS) headings. [17] investigate how new accounting information, concerning the firm's leverage level, influences firm's stock prices. They find that the impact of such information is an increasing function of debt levels.

An alternative stream of research gives emphasis on the role of information disclosure by firms. Accounting information is the key turning private into public information. This is the framework in which our study belongs. [18], through an equilibrium model, shows that information production is costly, implying the need for each investor to expend resources to collect the needed information. [3] analyze how disclosure affects the willingness of market makers to provide liquidity by investing in a particular stock. They also show that disclosure changes the risks to market makers, which in turn induces entry or exit by dealers. [1,19] show that disclosure is affected by insiders and strategic issues, while [20] use a structural microstructure model, which provides estimates information-based trading for a large cross section of stocks. [21] reaches the same conclusions only if the accounting practices, i.e. those that contribute to accounting information, are characterized as aggressive. [22] investigate the influence of accounting information on individual giving decisions through its impact on market liquidity and the cost of capital for business entities. However, their experimental empirical results display a minimal of such impact. Finally, [23] find that higher levels of accounting information and disclosure due to the adoption of IAS lead to higher excess returns, results that are consistent with the negative impact accounting information exerts on the cost of capital.

Finally, there are liquidity-based models that indirectly link accounting information and firm's expected stock 
returns. [24] make use of a model in which investors with different expecting holding periods prefer to trade assets with different relative spreads since they demand compensation for those spreads. As a result, expected stock returns are increasing with spreads. [9] show a model in which investors demand lower stock returns if such stocks have greater public and less private information.

The remainder of this paper is organized as follows. Section 2 presents the theoretical model and provides certain comparative static's. Finally, Section 3 concludes the paper.

\section{The Model}

\subsection{The Firm's Environment}

The equilibrium model we employ is a variation of [18]'s model and captures the interaction between firms and investors in equity markets as well as the fundamental role of accounting information in improving the efficiency of firms' investment decisions. In such a way, reporting accounting information has real effects that determine the firms' cost of capital. Poor accounting information leads to misaligned investments, which rational investors anticipate and price in equilibrium by discounting firms' expected cash flows at a higher rate of return.

Our model deals with an economy with $M_{j}$ firms, $j=1$, $2, \cdots, M$ and $a$ risk-free rate. Let $c_{j}$ and $P_{j}$ be the uncertain cash flows of firm $j$ and the market equilibrium price of firm $j$, respectively. We define the firm's $j$ cost of capital as the rate of return $R_{j}$ obtained from equating the price of firm $j$ to its expected cash flows:

$$
p_{j}=E\left(c_{j}\right) /\left(1+R_{j}\right) \text { or } R_{j}=E\left(c_{j}\right) / P_{j}-1
$$

Next, we assume that $n_{j}$ shows a measure of accounting information which is disclosed by firm $j$ to the firm's investors and the market. Our goal, as it was set above, is to determine whether an increase or decrease in firm's $j$ accounting information leads to a corresponding decrease or increase in the firm's $j$ cost of capital.

In the following step, we introduce a perfectly competitive market for firm's $j$ stocks comprised of $N_{i}$ investors, $i=1,2, \cdots, N$. Our investors are risk-averse. Without the hypothesis of risk aversion, the cost of capital turns out to be zero. Let also introduce an investor's utility function, represented by $U(c)$, where $c$ denotes an amount of cash. Each investor has a negative exponential utility function, yielding:

$$
U(c)=\alpha(1-\exp [-c / \alpha])
$$

where $\alpha>0$ and describes the investor's tolerance for risk. This particular utility function has the characteristic that as risk tolerance becomes unbounded, the utility function converges asymptotically to risk neutrality, i.e. $\lim U(c)=c$.

$$
\alpha \rightarrow \infty
$$

In a perfectly competitive market the market price for firm $j$ we define the vector $D_{i}=\left\{D_{i l}, \cdots, D_{i M}\right\}$ as the $1 \mathrm{xM}$ vector of investor's demand for ownership in $M$ firms. In other words, $D_{i j}$ displays investor's $i$ demand for firm $j$ expressed as a percentage of the total firms. If now $D_{i}{ }^{*}=\left\{D_{i 1}{ }^{*}, \cdots, D_{i M}{ }^{*}\right\}$ displays the vector of endowed ownership in firms, i.e. $D_{i j}{ }^{*}$ displays the investor's $i$ endowment in firm $j$ expressed as a percentage of the total firms. Next, we define $P=\left\{P_{l}, \cdots, P_{M}\right\}$ the vector of firm prices, i.e. $P_{j}$ displays the price of firm $j$. Finally, let $B_{i}$ and $B_{i}{ }^{*}$ be investor $i$ 's demand for a risk-free bond and his endowment in bonds, respectively. The problem we are called to solve yields:

$$
\max E\left[\alpha\left(1-\exp \left[-1 / \alpha\left(D_{i}\left\{c_{1}, \cdots, c_{M}\right\}^{\prime}+B_{i}\right)\right]\right)\right]
$$

w.t.r.t. $D_{i}, B_{i}$

or (see Equation (2))

w.t.r.t. $D_{i}, B_{i}$

where $V$ is an MxM covariance matrix with the t-thy term defined as: $\operatorname{Cov}\left(c_{s}, c_{t}\right)$ and $D_{i}$ and $B_{i}$ are the control variables of the system, subject to the following budget constraint:

$$
D_{i} P^{\prime}+B_{i}=D_{i}^{*} P^{\prime}+B_{i}^{*}
$$

The first order condition with respect to the variable $D_{i}$ yields:

$$
0=E\left(c_{j}\right)-P_{j}-1 / \alpha \sum_{s=1}^{M} D_{i s} \operatorname{Cov}\left(c_{j}, c_{s}\right)
$$

Since in the aggregate investors have claims to the cash flows of the entire firm, for each $\mathrm{s}$ it must be the case that:

$$
\sum_{i=1}^{N} D_{i s}=1
$$

Therefore, summing both sides of (3) with respect to $i$ yields:

$$
0=N\left[E\left(c_{j}\right)-P_{j}\right]-1 / \alpha \sum_{i=1}^{N} \sum_{s=1}^{M} D_{i s} \operatorname{Cov}\left(c_{j}, c_{s}\right)
$$

$$
\max \alpha\left(1-\exp \left[-1 / \alpha\left(D_{i}\left\{E\left(c_{1}\right)-P_{1}, E\left(c_{2}\right)-P_{2}, \cdots, E\left(c_{M}\right)-P_{M}\right\}^{\prime}+D_{i}^{*} P^{\prime}+B_{i}^{*}\right)+1 / 21 / \alpha^{2} D_{i} V D_{i}^{\prime}\right]\right)
$$


or

$$
0=N\left[E\left(c_{j}\right)-P_{j}\right]-1 / \alpha \sum_{s=1}^{M} \operatorname{Cov}\left(c_{j}, c_{s}\right)
$$

The last expression implies that the stock price for firm $j$ is defined as:

$$
P_{j}=E\left(c_{j}\right)-1 / N \alpha \sum_{s=1}^{M} \operatorname{Cov}\left(c_{j}, c_{s}\right)
$$

According to (4), the price for firm $j$ is equivalent to the one derived from the Capital Asset Pricing Model (CAPM). According to [25] and assuming that the risk free rate is zero, the CAPM is a market equilibrium pricing equation that yields the following association between firm's stock price and firm's cash flows:

$$
P_{j}=E\left(c_{j}\right)-\left[\left(E\left(c_{0}\right)-P_{0}\right) / \sigma_{0}^{2}\right] \operatorname{Cov}\left(c_{j}, c_{0}\right)
$$

where $c_{0}$ represents the sum of cash flows coming from all firms in the economy, i.e. the market portfolio, $\sigma_{0}^{2}$ represents the variance of the sum of all cash flows, while $P_{0}$ is the sum of the stock price of all firms. Equation (4) and the above expression together yield:

$$
P_{0}=E\left(c_{0}\right)-1 / N \alpha \sigma_{0}^{2}
$$

which, in turn, implies:

$$
\left[E\left(c_{0}\right)-P_{0}\right] / \sigma_{0}^{2}=1 / N \alpha
$$

The above expression constitutes the price of covariance (or non-diversifiable) risk in the economy. According to the above setting, the price of firm $j$ turns to be:

$$
P_{j}=E\left(c_{j}\right)-1 / N \alpha \operatorname{Cov}\left(c_{j}, c_{0}\right)
$$

Equation (5) is equivalent to Fama's CAPM model as a market equilibrium pricing equation.

\subsection{Cost of Capital}

In this section we will attempt to figure out what factors can influence the firm's $\mathrm{j}$ cost of capital. Our analysis is totally based on Equation (5) that describes the evolution of the firm's $j$ price of stock. To this end, we assume that firm's $\mathrm{j}$ cash flows are described by:

$c_{j}=a_{j}+b_{j} \theta+d_{j} \pi_{j}$

where $\theta$ denotes a random variable with mean zero and finite precision of $q, \pi$ is also a random variable with mean zero and finite precision of $h_{j}$, a is an intercept term, $b$ and $d$ are coefficients associated with the variables $\theta$ and $\pi$, respectively. We also assume that the $\pi_{j}$ 's are uncorrelated across firms. In addition, we assume that firm's $j$ cash flows have an element of common variation across firms through $\theta$ and an element of idiosyncratic variation through $\pi_{j}$. This issue captures that industry- or economy-wide events affect the cash flows of virtually all firms, while firm-specific or idiosyncratic events only affect the cash flows of firm $j$. The latter events are considered diversifiable and not priced through a CAPM framework. Within such a setting we get:

$$
\begin{aligned}
\operatorname{Cov}\left(c_{j}, c_{0}\right) & =\operatorname{Cov}\left(c_{j}, \sum_{s=1}^{M} c_{s}\right) \\
& =b_{j} \sum_{s=1}^{M} b_{s} E\left(\theta^{2}\right)+d_{j}^{2} E\left(\pi_{j}^{2}\right) \\
& =b_{j} \sum_{s=1}^{M} b_{s} 1 / q+d_{j}^{2} 1 / h_{j}
\end{aligned}
$$

The term $b_{j} \sum_{s=1}^{M} b_{s} 1 / q$ is considered to be the element of common variation in firm's $j$ cash flows with the market, while the term $d_{j}^{2} 1 / h_{j}$ is considered to be the element of idiosyncratic variation. If we substitute the whole expression into Equation (5), it yields:

$$
P_{j}=E\left(c_{j}\right)-1 / N \alpha b_{j} \sum_{s=1}^{M} b_{s} 1 / q+d_{j}^{2} 1 / h_{j}
$$

while the expression for $R_{j}$ yields as the Equation (6).

According to Equation (6), there are certain factors leading to the reduction of the firm's cost of capital:

- The decline of the variance in the idiosyncratic variation in firm's cash flows, $1 / h_{j}$,

- The decline of the variance in the common variation in firm's cash flows with the market, $1 / q$,

- The increase in the shareholder's base of the economy or alternatively the increase in the number of investors who participate in the market, $N$,

- The increase in the risk tolerance of the market, $\alpha$, and most crucially,

- The increase in the firm's j expected cash flows.

For satisfying the goal of this research paper, we focus on the last factor. More specifically, we saw that an increase in expected cash flows affected the firm's cost of capital $R_{j}$. This occurs because as long as expected cash flows increase, the price $P_{j}$ at which the market values the firm's stocks increases at a different rate. In other words, the effect on $R_{j}$ depends on how fast stock prices increase relative to expected cash flows, which, in turn, depends on the remaining parameters of the relevant expression, i.e. the covariance of the cash flows with the market or the degree of risk aversion.

$$
R_{j}=E\left(c_{j}\right) / P_{j}-1=1 / N \alpha\left[b_{j} \sum_{s=1}^{M} b_{s} 1 / q+d_{j}^{2} 1 / h_{j}\right] /\left[E\left(c_{j}\right)-b_{j} \sum_{s=1}^{M} b_{s} 1 / q+d_{j}^{2} 1 / h_{j}\right]
$$


Our next step involves us to determine when and how an increase or decrease in firm's accounting information leads to a corresponding decrease or increase in the firm's cost of capital. From the above we yield that an increase in firm's accounting information reduces either the variance in the idiosyncratic variation in firm's cash flows or investor's anticipations about that variance; in both cases the cost of capital decreases. In other words, an increase in disclosure of accounting information leads to lower investor's uncertainty about the parameters that matter for a secure pricing of the firm. Thus, in order to be consistent with the approach followed in [8], we must identify how the variables used there to proxy accounting information are related to the firm's cost of capital. In particular:

Cost of capital and leverage = according to pecking order behaviour, there exists a negative relationship between a firm's financial leverage and its cash flows. In particular, firms with higher internally generated cash flows require less debt. Firms with productive investment opportunities rely first on available cash flows to meet these financing needs. When such cash flows are depleted, the firm issues debt. This setting implies that debt acts as a residual of cash flows. Cross-sectional leverage studies that focus on the above mentioned contemporaneous relationship find extremely high support for such behaviour ([26-29]). Once we get a negative association between leverage and cash flows, Equation (6) predicts that there also exists a negative relationship between cash flows and cost of capital and thus we get a positive association between leverage and cost of capital as [8] find.

Cost of capital and interest coverage $=[30-32]$ focus on the 'balance-sheet effects' of cash flow shocks and argue that investment projects do not absorb a firm's entire cash-flow shock and that several competing allocations, such as cash saving and debt reduction, expand or contract a firm's potential for investment expenses. They display that high interest coverage indicates an inability to obtain debt financing, signalling relatively severe financial constraints. As a result, high interest coverage motivates firms to look for alternative financial sources. Depending on the availability of such alternative sources, the association between cash flows and interest coverage is blurred, while [33,34] argue that lower expected cash flows imply that firms have used those cash flows to finance their investment projects and are not motivated to turn to debt issues, thus, experiencing lower interest coverage. But, through Equation (6), lower cash flows are associated with a higher cost of capital, implying that interest coverage and cost of capital are both negatively associated, as [8] find.

Cost of capital and book values = the association be- tween cash flows and book values depends heavily on the size of firms. In particular, [35,36] argue that there exists a positive association between cash flows and book values for small firms, while the opposite is true for large firms.

Cost of capital and price-earnings ratio $=$ in case when the price-earnings ratio is positively driven by the future growth of firm's opportunities ([37,38]), then higher expected growth implies higher price-earnings ratios and higher expected cash flows, which, through Equation (6), lead to lower cost of capital, giving result to a negative association between price-earnings ratios and cost of capital as [8] find.

Cost of capital and betas = certain empirical studies have focused on how cash flows affect the firm's level of systematic risk or beta. In studies by $[39,40]$, a negative relationship is found. The rationale stems from how variances in dividends affect the timing of a firm's cash flows and, therefore, the level of systematic risk obtained by firm's potential investors, which, in turn, will affect the firm's cost of capital. Recently, [41] show that even by separating the motivation for paying a dividend from the immediate impact the dividend itself has on the firm, there is a clear negative relationship between cash flows and the systematic risk of the firm. Thus, this negative relationship, through Equation (6), implies that there also exists a positive relationship between betas and the cost of capital as [8] show.

\subsection{Earnings Quality and the Cost of Capital}

Finally, in this section we will extend the above model to account for the role of earnings quality. [42] documents a negative relationship between accruals and financial aggregates, such as stock returns. [43] investigate whether a higher level of quality for audit disclosures is used as a signalling mechanism about the future course of stock prices. Their results display that such higher quality levels of accounting disclosures have a substantial impact on firms' expected earnings and, thus, on their stock market returns. This empirical evidence provides strong support to the signalling value of audit quality levels. [44] also confirm that lower quality accounting information about certain accounting variables, such as accruals and earnings, undermines market efficiency and generates asset pricing anomalies. [45] investigate whether improvements in accounting information through a higher quality of announcements regarding accruals can be affected following regulatory interventions targeting the enhancement of accounting information for the case of the UK. They find that such an improvement does exist following the adoption of the FRS3 regulatory framework. 
Thus, to display how earnings quality can affect the firm's expected cash flows, we will present a case where each firm $j$ reports on its investment opportunities to the market. We also assume that investors provide managers with incentives to maximize the firm's market value. Therefore, managers select projects that maximize the market price, given the firm's report to the market. In other words, the quality of earnings affects investment choice, which, in turn, affects expected cash flows.

The effect of higher earnings quality is to improve the investment efficiency of the firm, without altering the firm's covariance with the market. The idea is that the firm's technology determines the covariance of the firm's cash flows with the market. Earnings quality simply affects the efficiency with which the investment project is implemented. In other words, what we want to show is that even when earnings quality is firm specific and has no effect on the covariance of the firm's cash flows, is expected to affect the cost of capital through its impact on expected cash flows.

In this setting, we assume that the firm's $j$ cash flows arise from a process in which an investment of an amount $k_{j}$ results in cash flow of $c_{j}=b_{j} \theta+k_{j} \pi_{i}-1 / 2 k_{j}^{2}$, where $\theta$ and $\pi_{j}$ are independent, normally distributed random variables with a mean 0 and precisions of $q$ and $h_{j}$, respectively, while $b_{j}$ is a positive, fixed coefficient. $k_{j}$ is firm's $j$ investment choice. The term $-1 / 2 k_{j}^{2}$ captures that there are diminishing returns to investment ([46]). We also assume that the $\pi_{j}$ 's are uncorrelated across firms.

We define $\pi_{j}$ as firm's $j$ earnings per unit of investment. It is an unknown variable to the market. However, each firm provides the market with a report, say $r_{j}$, of its earnings per unit of investment with some noise. That is:

$$
r_{j}=\pi_{j}-\varepsilon_{j}
$$

where the noise $\varepsilon_{j}$ has a normal distribution with mean 0 and precision $n_{j}$. Once again, noises across firms are assumed to be uncorrelated.

Let now $P_{j}\left(r_{j}\right)$ represent the price of firm $j$ conditional on a report about earnings: $P_{j}=E\left[P_{j}\left(r_{j}\right)\right]$. From Equation (6) we express $P_{j}\left(r_{j}\right)$ as:

$$
\begin{aligned}
P_{j}\left(r_{j}\right) & =E\left(c_{j} \mid r_{j}\right)-b_{j} b_{0} 1 / \alpha q \\
& =k_{j} E\left(\pi_{j} \mid r_{j}\right)-1 / 2 k_{j}^{2}-b_{j} b_{0} 1 / \alpha q \\
& =k_{j} n_{j} /\left(h_{j}+n_{j}\right) r_{j}-1 / 2 k_{j}^{2}-b_{j} b_{0} 1 / \alpha q
\end{aligned}
$$

Next, we assume that firm's $j$ investment choice is to maximize the firm's market price conditional on an earnings report. This particular assumption implies that the manager's information about $\pi$ plays no role; what really matters is the report to the market. More specifically, firms' investment opportunities are not observable to investors and not contractible. Thus, to overcome possible agency problems, stockholders provide incentives to maximize market values. Stock-based compensation is very common in practice and is widely suggested as a way to align the interests of managers and stockholders ([47]). To this end, we assume that incentives are a monotonically increasing function of the firm's market price.

Let now assume that $k k_{j}$ represents the investment choice that maximizes market prices conditional on the firm's report. The first order condition of maximizing $P_{j}\left(r_{j}\right)$ with respect to $k_{j}$ yields:

$$
k k_{j}=n_{j} /\left(h_{j}+n_{j}\right) r_{j}
$$

If we substitute the expression for $k k_{j}$ back into the expression for $P_{j}\left(r_{j}\right)$ yields:

$$
P_{j}=E\left[P_{j}\left(r_{j}\right)\right]=1 / 2 n_{j} /\left[\left(h_{j}+n_{j}\right) h_{j}\right]-b_{j} b_{0} 1 / \alpha q
$$

Next, let $c_{j}\left(r_{j}\right)$ represent the firm's $\mathrm{j}$ cash flows conditional on the firm's earnings report and an investment choice $k k_{j}$, where $E\left(c_{j}\right)=E\left[c_{j}\left(r_{j}\right)\right]$. Then:

$$
c_{j}\left(r_{j}\right)=k k_{j} n_{j} /\left(h_{j}+n_{j}\right) r_{j}-1 / 2 k k_{j}^{2}
$$

As a result:

$$
E\left(c_{j}\right)=E\left[c_{j}\left(r_{j}\right)\right]=1 / 2 n_{j} /\left[\left(h_{j}+n_{j}\right) h_{j}\right]
$$

In the last step, the expression for the firm's stock price and its expected cash flows implies the following for the firm's cost of capital:

$$
R_{j}=b_{j} b_{0} 1 / \alpha q /\left[1 / 2 n_{j} /\left\{\left(h_{j}+n_{j}\right) h_{j}\right\}-b_{j} b_{0} 1 / \alpha q\right]
$$

Next, through expression (7) we will determine how changes in earnings quality are associated with changes in $R_{j}$, which is, of course, our last goal here. We consider an increase in earnings quality of firm $j$, i.e. an increase in $n_{j}$. By taking the derivative of $R_{j}$ with respect to $\mathrm{n}_{\mathrm{j}}$ from expression (7) we yield:

$$
\begin{aligned}
& d\left(R_{j}\right) / \mathrm{d} n_{j}= \\
& \quad-\left[2 h_{j}^{2} b_{j} b_{0} 1 / \alpha q\right] /\left[n_{j}-2 h_{j}\left(h_{j}+n_{j}\right) b_{j} b_{0} 1 / \alpha q\right]^{2}<0
\end{aligned}
$$

According to the above derivative, an increase in earnings quality leads to the reduction of cost of capital, which verifies the findings by Apergis et al. (2010b). In other words, an increase in earnings quality increases investment alignment, which, in turn, increases expected cash flows, while has no effect on the covariance of these cash flows with the market. Thus, the market equilibrium price of those cash flows rises faster than the expectation of those cash flows, and the cost of capital declines. 


\section{Conclusions}

This theoretical study developed a simple equilibrium model to analyze the association between accounting information and firm's cost of capital and to verify or not previous empirical findings by the authors. We characterize asset prices in a market equilibrium setting with risk-averse investors. The findings showed that, even in a CAPM world, an increase in expected cash flows, coming from improvements in the quality of accounting information, leads to a reduction in the firm's cost of capital. Overall, the study provides a direct link between accounting information and the cost of capital that does rely on the fact that accounting information along with improvements in its quality has real effects on capital allocation that governs firm's cost of capital.

\section{Reference}

[1] A. Admati and P. Pfleiderer, "Forcing Firms to Talk: Financial Disclosure Regulation and Externalities," Review of Financial Studies, Vol. 13, No. 3, 2000, pp. 479519.

[2] A. Kyle, "Continuous Auctions and Insider Trade," Econometrica, Vol. 53, No. 6, 1985, pp. 1315-1355.

[3] D. W. Diamond and R. Verrecchia, "Disclosure, Liquidity, and the Cost of Capital," Journal of Finance, Vol. 56, 1991, pp. 1325-1359. doi:10.2307/2328861

[4] M. Brennan and A. Subramanyam, "Market Microstructure and Asset Pricing: On the Compensation for Illiquidity in Stock Returns," Journal of Financial Economics, Vol. 34, 1996, pp. 441-464. doi:10.1016/0304-405X(95)00870-K

[5] E. F. Fama and K. R. French, "Common Risk Factors in the Returns on Stocks and Bonds," Journal of Financial Economics, Vol. 33, No. 1, 1993, pp. 3-56. doi:10.1016/0304-405X(93)90023-5

[6] E. Bajo, "The Information Content of Abnormal Trading Volume," Journal of Business Finance and Accounting, Vol. 37, No. 7-8, 2010, pp. 950-978. doi:10.1111/j.1468-5957.2010.02197.x

[7] N. Apergis, G. Artikis, S. Eleftheriou and J. Sorros, "Accounting Information and the Cost of Capital: The Effect on Excess Stock Returns-Evidence from Panel Data," Working Paper No 13-2010, Department of Business Administration, University of Piraeus, 2010a.

[8] N. Apergis, G. Artikis, S. Eleftheriou and J. Sorros, "Accounting Information, the Cost of Capital and Excess Stock Returns: The Role of Earnings Quality-Evidence from Panel Data," Working Paper No 17-2010, Department of Business Administration, University of Piraeus, 2010b.

[9] D. Easley and M. O'Hara, "Information and the Cost of Capital," Journal of Finance, Vol. 59, No. 4, 2004, pp. 1553-1584. doi:10.1111/j.1540-6261.2004.00672.x
[10] C. Botosan, "Disclosure Level and the Cost of equity Capital," The Accounting Review, Vol. 72, No. 3, 1997, pp. 323-349.

[11] C. Botosan and M. Plumlee, "A Re-examination of Disclosure Level and the Expected Cost of equity Capital," Journal of Accounting Research, Vol. 40, No. 1, 2002, pp. 21-41. doi:10.1111/1475-679X.00037

[12] J. Francis, R. LaFond, P. Olsson and K. Schipper, "Costs of Capital and Earnings Attributes," The Accounting Review, Vol. 79, No. 4, 2004, pp. 967-1010. doi:10.2308/accr.2004.79.4.967

[13] R. C. Merton, "A Simple Model of Capital Market Equilibrium with Incomplete Information," Journal of Finance, Vol. 42, No. 3, 1987, pp. 483-510. doi: $10.2307 / 2328367$

[14] C. Barry and S. Brown, "Differential Information and Security Market Equilibrium," Journal of Financial and Quantitative Analysis, Vol. 20, No. 4, 1985, pp. 407-422. doi: $10.2307 / 2330758$

[15] J. Lewellen and J. Shanken, "Learning, Asset Pricing Tests, and Market Efficiency," Journal of Finance, Vol. 57, No. 3, 2002, pp. 1113-1145. doi:10.1111/1540-6261.00456

[16] M. Gietzmann and J. Ireland, "Cost of Capital, Strategic Disclosures and Accounting Choice," Journal of Business Finance and Accounting, Vol. 32, No. 3-4, 2005, pp. 599-634. doi:10.1111/j.0306-686X.2005.00606.x

[17] G. Feltham, S. Robb and P. Zhang, "Precision in Accounting Information, Financial Leverage and the Value of Equity," Journal of Business Finance and Accounting, Vol. 34, No. 7-8, 2007, pp. 1099-1122. doi:10.1111/j.1468-5957.2007.02027.x

[18] D. W. Diamond, "Optimal Release of Information by Firms," Journal of Finance, Vol. 40, No. 4, 1985, pp. 1071-1094.

[19] M. Fishman and K. Haggerty, "The Mandatory Disclosure of Trades and Market Liquidity," Review of Financial Studies, Vol. 8, 1997, pp. 637-676. doi:10.1093/rfs/8.3.637

[20] D. Easley, S. Hvidjkaer and M. O'Hara, "Is Information Risk a Determinant of Asset Returns?" Journal of Finance, Vol. 10, 2000, pp. 2185-2221.

[21] D. Ashton, "Discussion of Cost of Capital, Strategic Disclosures and Accounting Choice," Journal of Business Finance and Accounting, Vol. 32, No. 3-4, 2005, pp. 635-641. doi:10.1111/j.0306-686X.2005.00607.x

[22] S. Buchheit and L. M. Parsons, "An Experimental Investigation of Accounting Information's Influence on the Individual Giving Process," Journal of Accounting and Public Policy, Vol. 25, 2006, pp. 666-686. doi:10.1016/j.jaccpubpol.2006.09.002

[23] I. Karamanou and G. P. Nishiotis, "Disclosure and the cost of capital: Evidence from the Market's Reaction to Firm Voluntary Adoption of IAS," Journal of Business Finance and Accounting, Vol. 36, No. 7-8, 2009, pp. 793821. 
doi:10.1111/j.1468-5957.2009.02154.X

[24] Y. Amihud and H. Mendelson, "Asset Pricing and the Bid-Ask Spread," Journal of Financial Economics, Vol. 17, No. 1, 1986, pp. 223-249. doi:10.1016/0304-405X(86)90065-6

[25] E. F. Fama, "Foundations of Finance," New York, Basic Books, 1976.

[26] R. Masulis, "The Debt/Equity Choice," Ballinger Publishing Company, Cambridge, Mass, 1988.

[27] M. Harris and A. Ravin, "The Theory of Capital Structure," Journal of Finance, Vol. 46, 1991, pp. 297-356. doi: $10.2307 / 2328697$

[28] L. Shyam-Sunder and S. C. Myers, "Testing Static Trade-off against Pecking Order Models of Capital Structure," Journal of Financial Economics, Vol. 51, No. 3, 1999, pp. 219-244. doi:10.1016/S0304-405X(98)00051-8

[29] E. F. Fama and K. R. French, "Testing Trade-off and Pecking Order Predictions about Dividends and Debt," Working Paper, University of Chicago, 2000.

[30] S. M. Fazzari, R. G. Hubbard and B. C. Petersen, "Investment-Cash Flows Sensitivities are Useful: A Comment on Kaplan and Zingales," Quarterly Journal of Economics, Vol. 115, No. 2, 2000, 695-705. doi:10.1162/003355300554773

[31] S. N. Kaplan and L. Zingales, "Investment-Cash Flows Sensitivities are not Valid Measures of Financing Constraints," Quarterly Journal of Economics, Vol. 115, No. 3, 2000, pp. 707-712. doi:10.1162/003355300554782

[32] A. Hovakimian and G. Hovakimian, "Cash Flow Sensitivity of Investment", European Financial Management, Vol. 15, No. 2, 2009, pp. 47-65. doi:10.1111/j.1468-036X.2007.00420.x

[33] H. Almeida, M. Campello and M. S. Weisbach, "The Cash Flow Sensitivity of Cash," Journal of Finance, Vol. 59, No. 4, 2004, pp. 1777-1804. doi:10.1111/j.1540-6261.2004.00679.x

[34] B. D'Espallier and F. Lopez-Iturriaga, "On the Relation between Investment-Cash Flow Sensitivities and CashCash Flow Sensitivities," Working Paper No. 931, Katholieke Universiteit Leuven, 2008.

[35] S. H. Penman, "An Evaluation of Accounting Rate of Return," Journal of Accounting, Auditing, and Finance, Vol. 6, No. 2, 1991, pp. 233-255.

[36] E. F. Fama and K. R. French, "Size and Book-to-Market Factors in Earnings and Returns," Journal of Finance,
Vol. 50, No. 1, 1995, pp. 131-155. doi:10.2307/2329241

[37] S. Basu, "Investment Performance of Common Stocks in Relation to their Price-Earnings Ratios: A Test of the Efficient Market Hypothesis," Journal of Finance, Vol. 32, No. 3, 1977, pp. 663-682. doi:10.2307/2326304

[38] S. A. Ross, R. W. Westerfield and J. Jaffe, "Corporate Finance," McGraw-Hill, New York, 2002.

[39] C. F. Lee, P. Newbold, J. E. Finnerty and C. Chu, "On Accounting-Based, Market-Based, and Composite-Based Beta Predictions: Methods and Implications," The Financial Review, Vol. 21, No. 1, 1986, pp. 51-68. doi:10.1111/j.1540-6288.1986.tb01106.x

[40] E. Dyl and R. Hoffmeister, "A Note on Dividend Policy and Beta," Journal of Business Finance and Accounting, Vol. 13, No. 1, 1986, pp. 107-115. doi:10.1111/j.1468-5957.1986.tb01176.x

[41] M. Carter and B. H. Shawn-Schmidt, "The Relationship between Dividend Payouts and Systematic Risk: A Mathematical Approach," Academy of Accounting and Financial Studies Journal, Electronic On-Line Journal, 2008.

[42] R. Sloan, "Do Stock Prices Reflect Information in Accruals and Cash Flows about Future Earnings," The Accounting Review, Vol. 71, 1996, pp. 289-306.

[43] P. Lee, D. Stokes, S. Taylor and T. Walter, "The Association between Audit Quality, Accounting Disclosures and Firm-Specific Risk: Evidence from Initial Public Offerings," Journal of Accounting and Public Policy, Vol 22, No. 6, 2003, pp. 377-400. doi:10.1016/j.jaccpubpol.2003.08.003

[44] M. Drake, J. Myers and L. Myers, "Disclosure Quality and the Mispricing of Accruals and Cash Flow," SSRN: http://ssrn.com/abstract=985949, 2007

[45] A. L. C. Chan, E. Lee and S. Lin, "The Impact of Accounting Information Quality on the Mispricing of Accruals: The Case of FRS3 in the UK," Journal of Accounting and Public Policy, Vol. 28, No. 3, 2009, pp. 189-206. doi:10.1016/j.jaccpubpol.2009.04.002

[46] P. Fischer and R. Verrecchia, "Disclosure Bias," Journal of Accounting and Economics, Vol. 38, 2004, pp. 223-250.

[47] R. Lambert, "Contracting Theory and Accounting," Journal of Accounting and Economics, Vol. 32, 2001, pp. 3-8. 